\title{
INFORMATION TECHNOLOGIES, MECHATRONICS AND ROBOTICS AS A BASIS OF AN INTERDISCIPLINARY APPROACH TO ENGINEERING AND MEDICAL EDUCATION
}

\author{
L.Y. Ovsyanitskaya, larovs@rambler.ru \\ Ural Social-Economic Institute, Branch of the Labour and Social Relations Academy, \\ Chelyabinsk, Russian Federation,
}

E.V. Yurasova, iurasovaev@susu.ac.ru

South Ural State University, Chelyabinsk, Russian Federation

\begin{abstract}
Information technologies, robotics and mechatronics play an important role in modern medicine. The article shows that the use of information technology is an essential part of any activity of a specialist healthcare. The main goal of the medical technique development is the high accuracy and quality of service, efficiency of treatment, reducing the risk of harm to human health. However, despite advances in engineering and technology, health care professionals are not always aware of them, and engineers do not have full information on the needs of modern medicine. The article provides an analysis of the normative document that defines the strategy of the medical science development in the Russian Federation and analyzes the theoretical and practical background of the information technologies, mechatronics and robotics as a basis of an interdisciplinary approach in the development of medicine and engineering.

The authors determined the causes of the low interaction between health professionals and engineers in solving multidisciplinary problems. The main reason is the isolation of specialists in various fields of knowledge and the lack of a clear strategy for commercialization.

Pedagogical solutions to solve the problem are offered. The authors suggest that the approaches to the educational process should be changed. This will enable to improve the mutual understanding of health professionals and engineers in the course of continuing professional education. The result of training with the involvement of external experts will initiate research in their field, contributing to the global goal: the advancement of science in general.

Keywords: information technologies, mechatronics, robotics, health care professionals, continuing professional education.
\end{abstract}

\section{Introduction}

An integral part of any health care professional is the use of modern high-tech diagnostic and treatment centers in solving professional problems. The thousand-year history of the medicine formation as a science and health care as a branch of state activity is the cause of a particular relationship to the achievements in the field of scientific and technical progress. On the one hand, we see the need as the introduction of advanced information technology advances in medicine soon as possible on the other hand there is conservatism and repeated confirmation of the reliability of the results of new methods, tools and approaches.

In our country in recent years it has been conducted consistent policy aimed at creating preconditions for effective and high-quality information and technical support of the strategic and operational objectives of social and economic development of the Russian Federation, and ultimately the formation and development of the information society.

Dynamic social development suggests that the professional activity of the person should not been predetermined for the entire period of his career and provides the need for continuing education, that is, the process of continuous improvement of its competence. Computer science is not a specialized subject for medical students, so, unlike professional courses, it is not associated with the necessity of deep study. The need for knowledge of information technology comes later, when the doctor is faced with practical problems that must be solved independently.

The authors are directly involved in the practical development of high technology $[5,7,8]$, as well as in teaching activities aimed at the training of engineers and health professionals to work with modern hardware and software systems more than ten years. Over the years generations of computer equipment, technology and medical 


\section{Проблемы инженерного образования}

devices have been changed several times. This allowed the authors to observe the dynamics of health professionals training and specialized engineering in universities and draw conclusions about the need for the introduction of new organizational and pedagogical approaches to learning.

\section{Objectives, methodology}

\section{and research design}

In the 90 years of the last century, information technology has become an integral part of health care professionals, medical informatics education is an indispensable element of the doctor.

At present the development of science means the mutual process: on the one hand, there is the sciences derivation, associated with their increasing specialization, on the other hand the emergence of new studies is the result of the mutual penetration or symbiosis of different areas of knowledge. A striking example is the medical and technical sciences. Indeed, analysis of the latest achievements in this field shows the impossibility of an isolated development in these areas, as only their interaction with each other allows you to move to a higher level of quality [3].

On the one hand engineering provides the means to obtain new knowledge in medicine, on the other hand, they are the subject of research. The examples include the development of new architectures of computers and data processing algorithms (neurocomputers and neuroalgorithm) and the development of intelligent decisionmaking systems, which are based on the principles of the brain, creating robotic systems that simulate biomechanical objects $[4,9]$ and more. Thus we conclude that in modern science, no characteristics of the processes, phenomena of objects properties can not be studied in isolation, since it is impossible to draw a clear line between where one sphere of science ends and the other science begins.

However today in spite of the great achievements in the development of innovative medical facilities and technology, there are serious problems that are rapidly engage them in scientific and economic turnover. The problem is that doctors are often unaware of the opportunities that have become available in recent years developers of medical and diagnostic equipment, and engineers, in turn, are not always aware of the needs of physicians. The reason for this paradox is the isolation of specialists in various fields of knowledge, the objective difficulties (financial, organizational) that do not allow them to participate directly in scientific conferences on subjects of other sciences, where we discuss promising areas of this field of knowledge, lack of adequate information support innovative projects.

The reasons for delays in informing and mutual introduction of technologies is the lack of interagency planning market-oriented research, most of which currently maintains a narrow specialization does not meet the investment attractiveness, does not contain any analysis of the prospective market information and the clear strategy for commercialization. As a result, a lot of ideas, interesting solutions and original development of mechatronics in the most "critical" areas of modern science and technology, there is still no demand for implementation in other areas, because of these developments informed only a narrow circle of specialists.

The Strategy of development of medical science in the Russian Federation for the period up to 2025 has been approved by the Federal Government [2]. The aim of the Strategy is the development of medical science, aimed at the creation of high-tech innovative products that provide the basis for the transfer of innovative technologies in the practical health preservation and strengthening of health.

The strategy is aimed at implementation of the state policy in the field of health care, improving the quality and accessibility of health care to the population of the Russian Federation, including the development of innovative products, development of critical technologies and the development of competencies. To achieve these goals it provides the solution of the examination system (informed choice) perspective development problems and priorities evaluate the quality and effectiveness of research and the creation of conditions for sustainable demand for innovative products and its implementation in practical health.

Mechatronics and Robotics are the directions, including the complex of ideas, methods and tools for creating information-controlled and programmable mechanical systems with dedicated functions [6]. These are system philosophical disciplines, form the basis of any automation objects of human life, and therefore they should be the subject of study almost all specialties.

Mechatronics is traditionally perceived as a part of the overall educational process with robotics, which is officially registered in the list of educational areas. However, more accurately regarded as mechatronics and robotics selfdiscipline, having a common subdomain in the 
form of robotic systems and their components, using similar principles, methods of design and research.

To clarify this definition, many scientists from around the world have developed various charts that reveal the essence of mechatronics. One of them (proposed MIREA) is shown in Figure. This logo demonstrates the interdisciplinary nature of mechatronics. Robotics should be considered as a wide range of modern technologies at the junction of the key branches of science. Speeding up work in this direction is not a fashion trend, and a recognized need, which is important for the state and its security, economic and social spheres [1]. The course will include robotics in school curricula "technology" with the new school year. This was announced on 21.11.2014, the "Days of robotics in Sochi" Education and Science Minister Dmitry Livanov. He believes the educational robotics important area of work, which allows us to develop interdisciplinary training and communication competence of students: mathematics, physics, engineering, design, drawing - all that children use while designing robots.

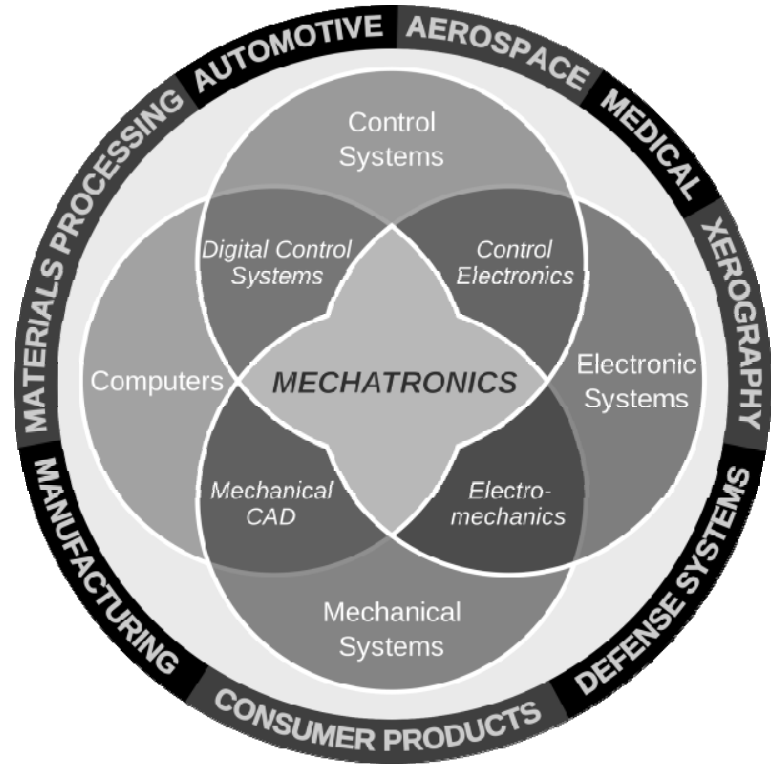

The logo of mechatronics

Current educational standards of general education intended to develop more skills to learn, not to get the required amount of knowledge. Mechatronics and Robotics contribute to this process better, allowing to transform the school curriculum of the scholastic and requiring memorization in the process of active cognitive activity on the principle of active research.
Changes caused by the development of Robotics and Mechatronics, will increase the possibility of engineering and leads to the restoration of the prestige of engineering specialties that should be considered when drawing up curricula in universities and further education of engineers and undergraduate through graduate, postgraduate and doctoral studies.

Currently robots are playing a great role in the development of modern medicine. Medicine is becoming one of the main vectors of introduction of robots and artificial intelligence. The main goal of the development of medical robotics is the high accuracy and quality of service, efficiency of treatment, reducing the risk of harm to human health. Thus understanding the role of mechatronics and robotics as an integral component of the development of medicine and the role of medicine in the development of mechatronics and robotics, we hypothesized that the pedagogical approach to training doctors and engineers in related fields should also be based on the interaction of these sciences.

In conducting activities within the training as health professionals and engineers, there is a situation in which students and teachers have become almost equal participants in the educational process. In the case where the classes are held at the health professionals, the teacher is the expert in the field of computer science and engineering. Where in the real world it can learn about the needs of modern medicine in different areas? Only listeners training cycles, representing different regions and branches of medicine.

In the case where the training is carried out by specialists associated with the development of modern technology, you need an invitation to biologists and biomechanics, which, in the course of employment, and themselves learn a great deal about the current developments in the field of science and technology.

Consider the pedagogical conditions to implement the process of implementing the identified requirements.

\section{Discussion of the research outcomes}

Above we have assumed that medicine and computer science decides interconnecting problems as a whole. Therefore, the teacher of information technology, modern medical equipment and students, health professionals must work together to build the learning process so as to contribute to each other, each within their competencies and erudition, in search of answers to their 


\section{Проблемы инженерного образования}

questions and, more important, the emergence of new issues.

Schematically the learning process can be represented as a process of learning management with the mandatory feedback from the students to the teacher. Vocational training of teachers, and the presence of intuition developed a tiered lecture material, manuals and control activities promote competent management of the conversation and the resulting transformation of heterogeneous information (facts, ideas, suggestions, examples of personal and professional experience) in the high-quality knowledge that can be practiced the audience immediately after training.

Initiation of discussions on issues related to health information specific medical institutions, organizing public process solutions case studies make the actual occupation, helpful and highly professional. Random remarks and questions from the audience, arising during the interview are often important and interesting for everyone. Proper management of the educational process can lead to new knowledge and skills that are difficult to foresee was impossible.

\section{Conclusion}

Summing up the results of study we note that its relevance is determined by:

- high rates of science and technology development;

- the need for training of qualified health professionals who are ready to work with hightech digital equipment and software products based on ultra-fast technological growth, robotics and medicine development of biotechnology;

- the need to train qualified engineers and technicians, possessing knowledge about the needs of medicine in new therapeutic and diagnostic equipment;

- high level requirements and relevance of these subjects teachers knowledge.

One of the main factors influencing the development of innovative medical robotics is deep awareness of the health and robotics engineers in mutual needs and modern achievements.

Necessary to attract health professionals to cycle training engineers and robotics engineers at the postgraduate training of doctors. Wellformed structure of employment will allow the student to learn about new opportunities to study science, to promote (through its administrative and professional opportunities) implementation in public health practice methods, devices, and technologies; be competent persons, i.e. not only possess modern means of transformation and information technology, but also possess erudition, which applies these devices and technologies to resolve any problems arising in practice, including in the face of uncertainty and using intelligent and heuristic methods.

The result of training with the involvement of external experts is to initiate research in their field, contributing to the global goal: the advancement of science in general.

\section{References}

1. Nazarenko K.A., Dubinin E.S., Cherednikov A.A. [The Model of the Robot Simulator Unconditioned Reflexes Newborn]. BMIK, 2014, no. 5, pp. 692. (in Russ.)

2. Prikaz ot 28.12.2012 № 2580-r "Ob utverzhdenii Strategii razvitiya meditsinskoy nauki v Rossiyskoy Federatsii na period do 2025 goda" [Order of the Government of the Russian Federation from 28.12.2012 No. 2580-r "On Approval of the Strategy of Development of Medical Science in the Russian Federation until 2025"]. Available at: http://government.ru/docs/7257/ (accessed 30.05.2015).

3. Ovsyanitskaya L.Yu. [Application of Andragogical Approach as a General Scientific Basis for the Formation of Information Competence of Health Professionals]. Bulletin of the Tomsk State University, 2015, no. 390, pp. 194-201. (in Russ.)

4. Smelyagin A.I., Babenko E.V. [Modeling of the Structure of Robots and Manipulators]. Bulletin of UNN, 2011, no. 4-2, pp. 315-317. (in Russ.)

5. Smirnov Yu.S., Yurasova E.V., Kozina T.A. [Multifunctional Phase Displacement Transducer]. XII Vserossiyskoe soveshchanie po problemam upravleniya VSPU-2014 [XII Russian Meeting on the Management]. Moscow, 2014, pp. 7171-7182. (in Russ.)

6. Smirnov Yu.S. Elektromekhatronne preobrazovateli [Ectromechatronics Converters]. Chelyabinsk, South Ural St. Univ. Publ., 2013. 360 p. (in Russ.)

7. Smirnov Yu.S., Katsay D.A., Yurasova E.V., Nikitin I.S. [Improving the Efficiency of Formation Equivalents of Displacement Components]. Materialy konferentsii "Informatsionnye tekhnologii $v$ upravlenii" (ITU-2014) [Materials of Conference "Information Technologies in Management"]. St. Petersburg, 2014, pp. 710-719. (in Russ.) 
8. Smirnov Yu.S., Kozina T.A., Yurasova E.V., Sokolov A.V. [Analog-to-Digital Converters of the Components of a Displacement with the Use of Microelectronic Sine-Cosine Magnetic Encoders]. Measurement Techniques, 2014, vol. 57, iss. 1, pp. 41-46. (in Russ.) DOI: 10.1007/s11018-014-0404-5

9. Zagorul'ko Yu.A. [Modeling the Robot Managed Voice Signals]. Proceedings of TPU, 2011, no. 5, pp. 98-102. (in Russ.)

Received 31 August 2015

\title{
ИНФОРМАЦИОННЫЕ ТЕХНОЛОГИИ, МЕХАТРОНИКА И РОБОТОТЕХНИКА КАК ОСНОВА МЕЖДИСЦИПЛИНАРНОГО ПОДХОДА В ИНЖЕНЕРНОМ И МЕДИЦИНСКОМ ОБРАЗОВАНИИ
}

\author{
Л.Ю. Овсяницкая ${ }^{1}$, Е.В. Юрасова ${ }^{2}$ \\ ${ }^{1}$ Уральский социально-экономический институт (филиал) \\ Академии труда и социальных отношений, г. Челябинск, \\ ${ }^{2}$ Южно-Уральский государственный университет, г. Челябинск
}

Информационные технологии, мехатроника и робототехника в настоящее время играют важную роль в развитии современной медицины. В статье показано, что использование информационных технологий является обязательной составляющей деятельности специалиста любой сферы здравоохранения. Повышение качества обслуживания и эффективности лечения, уменьшение рисков нанесения вреда здоровью человека становятся главной целью развития современной медицинской техники. Несмотря на достижения в области медицинской техники и технологий, в настоящее время специалисты здравоохранения не всегда имеют достаточную информацию о них, а технические специалисты не владеют полными сведениями о потребностях современной медицины. В статье приведен анализ нормативного документа, определяющего Стратегию развития медицинской науки в Российской Федерации, и проведен анализ теоретических и практических предпосылок рассмотрения информационных технологий, мехатроники и робототехники как основы междисциплинарного подхода в развитии медицины и инженерии.

В результате исследования авторами определены причины возникновения низкого взаимодействия врачей и технических специалистов при решении задач из междисциплинарных областей. Доказано, что основной причиной сложившейся ситуации является изолированность специалистов различных областей знаний и отсутствие необходимого информационного и педагогического обеспечения современных проектов. Предложены педагогические пути решения описанного парадокса путем изменения подходов к ведению занятий на циклах непрерывного профессионального образования врачей и других специалистов здравоохранения и инженеров, специализирующихся в области медицинской робототехники, ведущих к повышению уровня их взаимопонимания. Результатом обучения с привлечением внешних специалистов является инициирование научных исследований в своей области, способствующей глобальной цели: прогрессу науки в целом.

Ключевые слова: информаџионные технологии, мехатроника, робототехника, специалисты здравоохранения, непрерывное профессиональное образование. 


\section{Проблемы инженерного образования}

Литература
1. Назаренко, К.А. Модель робота-симулятора безусловных рефлексов новорожденного / К.А. Назаренко, Е.С. Дубинина, А.А. Чередников // БМИК. - 2014. - № 5. - С. 692.

2. Распоряжение Правительства РФ от 28.12.2012 № 2580-р «Об утверждении Стратегии развития медиџинской науки в Российской Федераџии на период до 2025 года». - http://government. ru/docs/7257/ (дата обращения: 30.05.2015).

3. Овсяниикая, Л.Ю. Применение андрагогического подхода как общенаучной основы формирования информационной компетентности специалистов системы здравоохранения / Л.Ю. Овсяницкая // Вестн. Том. гос. ун-та. - 2015. - № 390. - С. 194-201.

4. Смелягин, А.И. Моделирование структуры роботов и манипуляторов / А.И. Смелягин, Е.В. Бабенко // Вестник ННГУ. - 2011. - № 4-2. - C. 315-317.

5. Смирнов, Ю.С. Полифункииональный фазовый преобразователь перемещения / Ю.С. Смирнов, Е.В. Юрасова, Т.А. Козина // ХІІ Всероссийское совещание по проблемам управления ВСПУ-2014. М.: ИПУ им. В.А. Трапезникова РАН, 2014. - C. 7171-7182.

6. Смирнов, Ю.С. Электромехатронные преобразователи / Ю.С. Смирнов; под ред. А.Л. Шестакова. - Челябинск: Издат. иентр ЮУрГУ, 2013. - 360 с.

7. Повышение эффективности формирования эквивалентов составляющих перемещения / Ю.С. Смирнов, Д.А. Качай, Е.В. Юрасова, И.С. Никитин // Материалы конференции «Информаиионные технологии в управлении» (ИТУ-2014). - СПб.: ОАО «Конщерн «ЦНИИ «Электроприбор», 2014. - C. 710-719.

8. Analog-to-Digital Converters of the Components of a Displacement with the Use of Microelectronic Sine-Cosine Magnetic Encoders / Yu.S. Smirnov, T.A. Kozina, E.V. Yurasova, A.V. Sokolov // Measurement Techniques. - 2014. - Vol. 57. - Iss. 1. - P. 41-46.

9. Загорулько, Ю.А. Моделирование робота, управляемого речевыми сигналами // Известия ТПУ. - 2011. - № 5. - C. 98-102.

Овсяницкая Лариса Юрьевна, кандидат технических наук, доцент кафедры прикладной информатики и математики, Уральский социально-экономический институт (филиал) Академии труда и социальных отношений (г. Челябинск), larovs@rambler.ru.

Юрасова Екатерина Валерьевна, кандидат технических наук, доцент, доцент кафедры информационно-измерительной техники, Южно-Уральский государственный университет (г. Челябинск), iurasovaev@susu.ac.ru.

Поступила в редакцию 31 августа 20152.

\section{ОБРАЗЕЦ ЦИТИРОВАНИЯ}

Ovsyanitskaya, L.Y. Information technologies, mechatronics and robotics as a basis of an interdisciplinary approach to engineering and medical education / L.Y. Ovsyanitskaya, E.V. Yurasova // Вестник ЮУрГУ. Серия «Образование. Педагогические науки». - 2015. - Т. 7, № 4. C. 101-106. DOI: 10.14529/ped150414

\section{FOR CITATION}

Ovsyanitskaya L.Y., Yurasova E.V. Information Technologies, Mechatronics and Robotics as a Basis of an Interdisciplinary Approach to Engineering and Medical Education. Bulletin of the South Ural State University. Ser. Education. Educational Sciences. 2015, vol. 7, no. 4, pp. 101-106. DOI: 10.14529/ped150414 